\title{
INFLUENCE OF DRAINAGE RECONSTRUCTION ON RADIAL INCREMENT OF CONIFERS: CASE STUDY
}

\author{
*Baiba Jansone ${ }^{1,2}$, Linards Sisenis ${ }^{1}$, Irina Pilvere ${ }^{1}$, Marcis Vinters ${ }^{1}$, Karlis Bickovskis ${ }^{2}$ \\ ${ }^{1}$ Latvia University of Life Sciences and Technologies, Latvia \\ ${ }^{2}$ Latvian State Forest Research Institute 'Silava', Latvia \\ *Corresponding author's email: baiba.jansone@1lu.lv
}

\begin{abstract}
Drainage ensures flow of water and access of oxygen to the roots of the trees. Therefore, melioration systems have been established in a third of the forest area of Latvia, and for the most part highly productive stands can be observed in these areas. Water flow in these systems is often stopped by beaver dams. The aim of our case study was to assess the impact of ditch reconstruction on the increment of the coniferous trees. Increment cores were collected from 169 trees at a distance up to $45 \mathrm{~m}$ from the ditch in the drainage system that was reconstructed 8 years prior.

Drainage system reconstruction reversed the trend of declining radial increment for both Scots pine and Norway spruce; however, the influence of this measure over an 8 year period was statistically significant, notable (55\%) and positive only for Norway spruce, growing closest to the edge of the ditch. Other growth limiting factors need to be considered and tackled to ensure the highest effect of the investment in drainage system reconstruction, including choice of the tree species, stand density, age, availability of nutrients.
\end{abstract}

Key words: ditch, Pice abies, forest management, growth response, growth release.

\section{Introduction}

Drainage (melioration) has been the most important factor, increasing forest productivity in Latvia over the last half a century. Notable share $(32 \%$, based on National Forest Inventory data) of our forests currently are located on drained soils. Additionally, increased growth (current annual increment) had attributed to Climate change (Pretzsch et al., 2014). This effect, however, differs between tree species, and has been notable for Norway spruce (Picea abies (L.) Karst.) already at young (up to 40 years) age (Pretzsch et al., 2014). Similarly, a relatively long-lasting influence of fertilization, has been observed of the tree species (Jansons et al., 2016a). The increment (productivity) of the trees can be even further raised by influence of climate in combination with changes in silviculture e.g., tailored soil preparation, tending, different stand density (Dzerina et al., 2016; Celma et al., 2018; Katrevics et al., 2018; Katrevičs et al., 2018). Also, application of tree breeding results, currently a very common practice for Scots pine (mostly planted, all plants grown from seed orchard seeds) and Norway spruce (almost exclusively planted, most of plants form seed orchard seeds), can substantially increase the growth (Jansons, Gailis, \& Donis, 2011; Jansons et al., 2015a). Increase in stem volume growth of at least $10 \%$ by selecting a seed source can be achieved (Janson et al., 2013), as well as increased the above-ground biomass (Lībiete-Zālīte \& Jansons, 2011; Lībiete et al., 2017); these figures are affected by genotype-environment interaction (Janosns et al., 2008). Relative high realized gain values are especially true if vegetatively propagated material is used in regeneration (Zeltiňš et al., 2018b). The use of improved material does not lead to notable reduction of genetic diversity (Rungis et al., 2019). However, careful selection of clones not only by growth, but also by resistance is essential to ensure a good outcome of valuable assortments and minimize the potential negative influence of Climate change (Zeltins et al., 2016, 2018a). Ongoing changes in climate, as predicted currently, might lead to limits of phenotypic plasticity of trees (Schmidt-Vogt, 1977). Limiting factors, like summer drought (Jansons et al., 2015b; Matisons et al., 2017) might have increasingly more influence on the total increment. Also, increasingly favourable conditions for dendrophagous insects (Bāders et al., 2018) can lead to larger areas of low survival and/or growth of forests. Selection of robust seed sources (provenances), suitable for respective conditions and fast growth might be part of the solution (RiekstsRiekstins et al., 2014; Matisons et al., 2018).

In Europe, damages in forests are caused by fires, wind storms and bark beetles (Seidl et al., 2014; Kitenberga et al., 2018, 2019). However, in the areas with excess water due to precipitation or ground water regime (usually the case in Latvia) is also a growth limiting factor to a large extent. All of these factors can be at least to some extent influenced by behavior change or management activities (Donis et al., 2017). Water regime is relatively difficult to change, and it requires a significant financial investment. Therefore, assessment of the potential gain (revenue) in terms of additional tree growth is important to ensure, that the additional value, planed by this activity, can actually be achieved.

The aim of our case study was to assess the impact of ditch reconstruction on the increment of the coniferous trees.

\section{Materials and Methods}

Data were collected in the central part of Latvia, in the mild (maritime) climatic conditions - in this region 


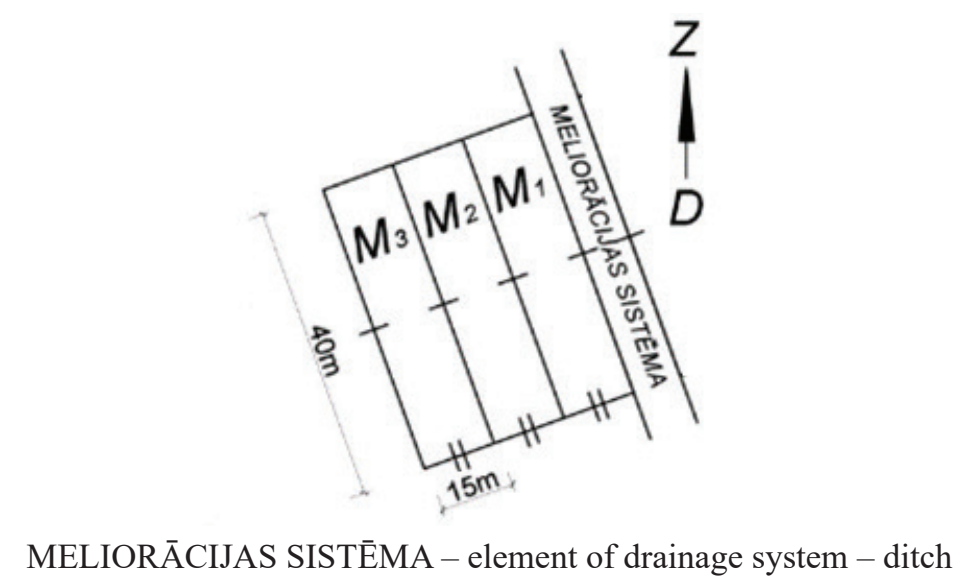

Figure 1. Allocation of sample plots.

30-years mean air temperature in July and January was +18 and $-6^{\circ} \mathrm{C}$, respectively. Frost-free period was 140 days on average; annual sum of precipitation varies between 700 and $800 \mathrm{~mm}$. Relief is generally flat, low elevation above the sea level, thus the maintenance of drainage system is important to ensure water flow.

In the forest type with fertile drained peat soil (Myrtillosa turf. mel.), sample plots were placed systematically, parallel to the ditch, in different distances from it (Figure 1). In this forest type, peat consists primarily from the elements of trees and vascular plants.

Mixed stand, including Scots pine and Norway spruce in similar proportions (in M1 and M2) and admixture of birch (in M3) were selected. Drainage system was established in 1981 and cleaned, mainly from the beaver dams, blocking the water flow (reconstructed) in 2010.

All trees were measured (height and diameter at breast height - DBH). Increment cores were collected from the breast height from altogether 169 trees, randomly selected from different diameter classes. Cores were sanded and increments measured with LINTAB.

\section{Results and Discussion}

Mean height and DBH was similar for both coniferous tree species with slightly higher values of Scots pine. Height ranged from 20.1 $\pm 0.7 \mathrm{~m}$ (here and further in text: $\pm 95 \%$ confidence interval) to $21.4 \pm 0.6 \mathrm{~m}$ for spruce and from $20.6 \pm 0.6 \mathrm{~m}$ to $23.6 \pm 0.6 \mathrm{~m}$ for pine; respective figures for $\mathrm{DBH}$ were from $19.5 \pm 1.6 \mathrm{~cm}$ to $22.9 \pm 3.9 \mathrm{~cm}$ and from $23.0 \pm 2.3 \mathrm{~cm}$ to $24.4 \pm 1.9 \mathrm{~cm}$. The mean breast height age for both coniferous tree species was 56 years.

Notable reaction to the reconstruction of drainage system - thus the availability of the oxygen to the root system of trees - can be observed for Scots pine and Norway spruce (Figures 2, 3). Even so, for Scots pine the reaction was pronounced only in the area close to the ditch (M1) and not long-lasting; after a few years the on-going downward trend of the annual ring-width

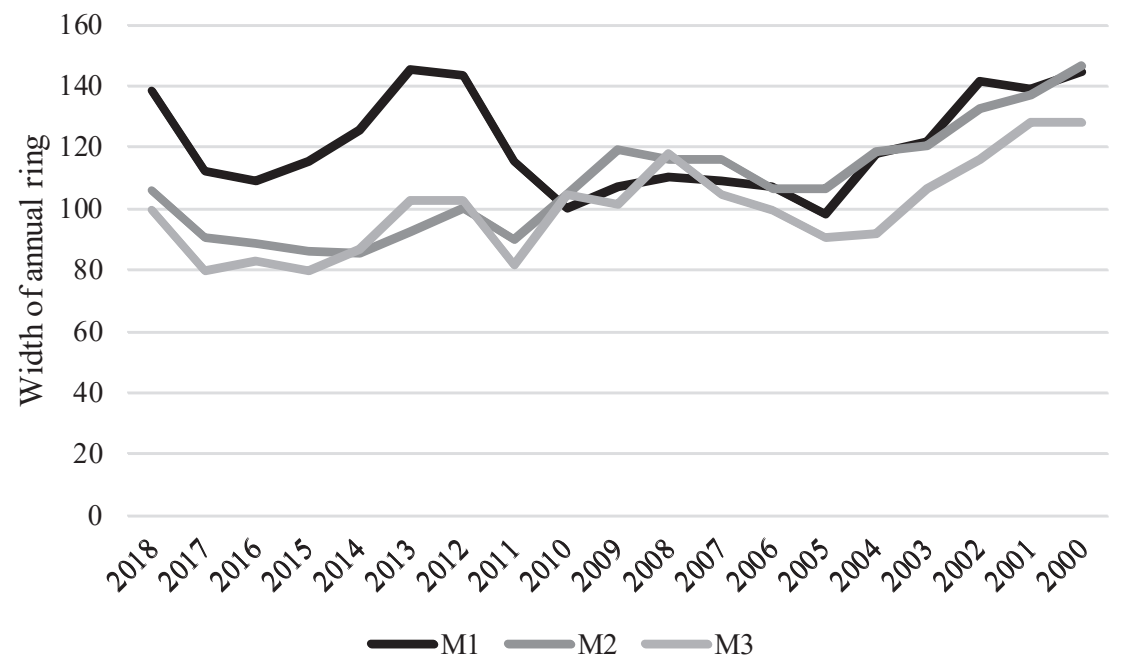

Figure 2. Changes in annual ring width for Scots pine. 


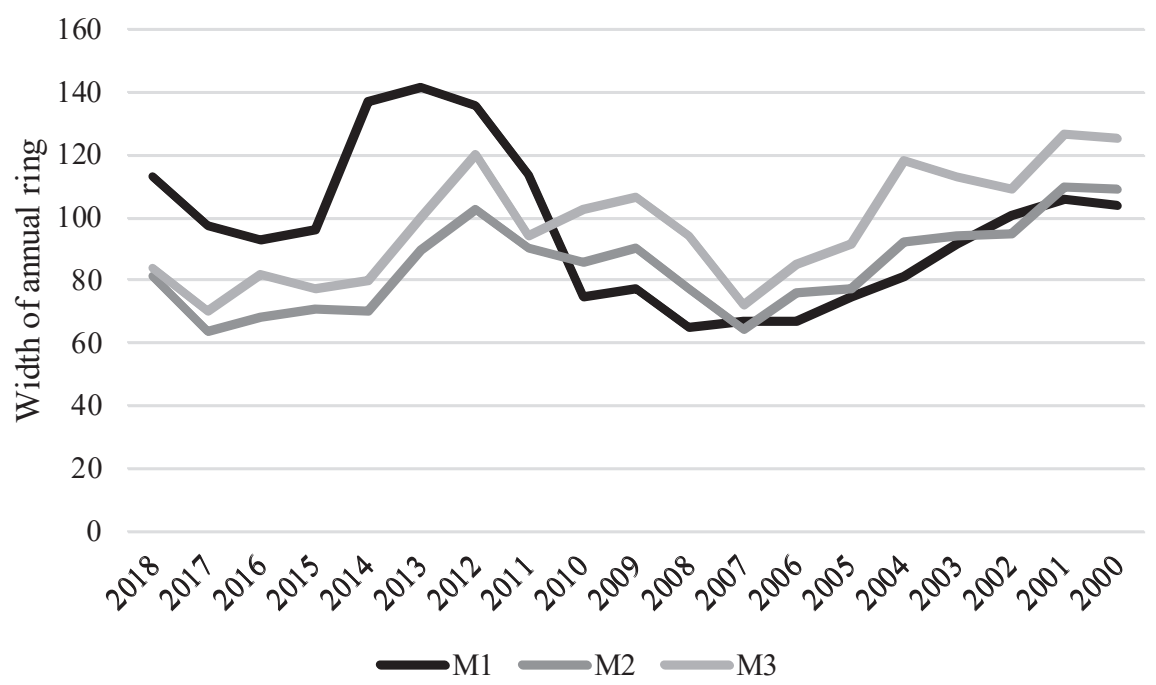

Figure 3. Changes in annual ring width for Norway spruce.

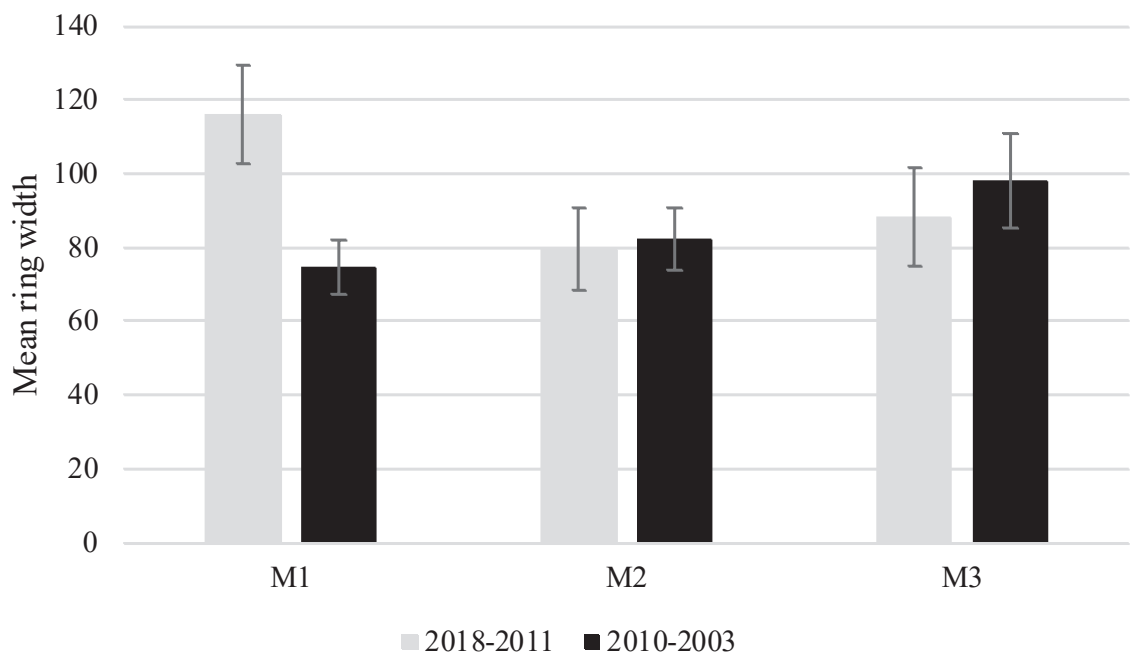

Figure 4. Mean annual ring width for Norway spruce.

continued. Presumably, it might be the result of rather high stand density - basal area reaching 37-41 $\mathrm{m}^{2} \mathrm{ha}^{-1}$ in M2 and M3, and $28 \mathrm{~m}^{2} \mathrm{ha}^{-1}$ in M1. Stand density is a significant factor, affecting the increment of trees for a long period of time: initially sparse stands have notably larger DBH than dense even at the age of c.a. 50 years (Katrevičs et al., 2018). It is at least partly related to the development of the green crown - thus the capacity of production of organic matter. Pruning experiments had clearly demonstrated that the removal of lower branches from the green crown have no negative impact on the radial increment (Baders et al., 2017); however, the length of the green crown has.

In such a high density the radial increment of trees, especially of light demanding ones (pine), was negatively affected. It could explain, why for this tree species the mean ring width in an 8 -year interval prior to drainage system reconstruction (year 2003-
2010) was not significantly different than in an 8 year interval (years 2011-2018) after it.

Norway spruce also demonstrated rather sharp rise of the increment after drainage system reconstruction, followed by a few years of its drop. However, the comparison of mean annual ring width over a longer period of time before and after the drainage system reconstruction clearly demonstrates that closer to the ditch statistically significant, notable (by 55\%) increase occurred (Figure 4). It might be both related to the shade tolerance (also higher density stand trees react to the improved conditions) as well as to higher sensitivity to excess water for Norway spruce. Such sensitivity had been demonstrated both for radial (Jansons et al., 2016b) and height increment for trees at different age, including on formation of lammas growth at the end of the vegetation season (Katrevics et al., 2018). 
The observed relative weak influence from the investment in the drainage system reconstruction might be also related to the age related trend (Jansons et al., 2016b). Also, lack of mineral elements to some extent might be contributing - it has been shown, that even a single initial fertilization has long (up to 15 years) lasting positive influence on the radial increment of Norway spruce (Jansons et al., 2016a).

Relative stand density reached 0.8 in the M1 and 1.1 in the M2 and M3. Even though the tree diameter was not significantly affected before the drainage system reconstruction (mean diameter was not significantly different), the trees might be able to react to improved conditions. In the high density stands trees, especially of the light demanding species, they tend to lose the green crown rapidly. Even after the conditions improvement (after the thinning or natural disturbance e.g. windstorm), there is not sufficient amount of foliage for rapid response and growth of stem. Besides, trees in such conditions after release might be unstable (Donis et al., 2018), thus allocating more of the resource to root growth than to above-ground growth. Tree reaction to the drainage system reconstruction might be limited also due to un-visible under-ground water flaw also in seemingly over-grown ditches. However, such flow would be stopped by the beaver dams.

\section{Conclusions}

1. Drainage system reconstruction reversed the trend of declining radial increment (presumably related to tree age and stand density) for both Scots pine and Norway spruce.

2. Influence of this measure over a longer period of time (8 years) was statistically significant and positive for Norway spruce, growing close to the edge of the ditch.

3. To ensure the highest effect of the investment in drainage system reconstruction, it needs to be combined with other forest management measures, aimed at different growth-limiting factors, e.g. thinning.

\section{Acknowledgements}

The study was supported by LLU project 'Assessment of the influence of beaver created rise of water level on productivity of forest stands'.

\section{References}

Baders, E., Donis, J., Snepsts, G., Adamovics, A., \& Jansons, A. (2017). Pruning effect on Norway spruce (Picea abies (L.) Karst.) growth and quality. Forestry Studies, 66, 33-48.

Bāders, E., Jansons, Ā., Matisons, R., Elferts, D., \& Desaine, I. (2018). Landscape diversity for reduced risk of insect damage: a case study of Spruce bud Scale in Latvia. Forests. 9, 545; DOI: 10.3390/f9090545.

Celma, S., Blate, K., Lazdiņa, D., Dūmiņš, K., Neimane, S., Štāls, T.A., \& Štikāne, K. (2018). Effect of soil preparation method on root development of P. sylvestris and P. abies saplings in commercial forest stands. New Forests. 50 (2), 283-289. DOI: 10.1007/s11056-018-9654-4.

Donis, J., Kitenberga, M., Snepsts, G., Dubrovskis, E., \& Jansons, A. (2018). Factors affecting windstorm damage at the stand level in hemiboreal forests in Latvia: case study of 2005 winter storm. Silva Fennica. Vol. 52 No. 4 article id 10009. DOI: 10.14214/sf.10009.

Donis, J., Kitenberga, M., Snepsts, G., Matisons, R., Zarins, J., \& Jansons, A. (2017). The forest fire regime in Latvia during 1922-2014. Silva Fennica. 51 (5), DOI: 10.14214/sf.7746.

Dzerina, B., Girdziusas, S., Lazdina, D., Lazdins, A., Jansons, J., Neimane, U., \& Jansons, Ā. (2016). Influence of spot mounding on height growth and tending of Norway spruce: case study in Latvia. Forestry Studies. 65, 24-33. DOI: 10.1515/fsmu-2016-0009.

Haapanen, M., Jansson, G., Nielsen, U.B., Steffenrem, A., \& Stener, L.G. (2015). The status of tree breeding and its potential for improving biomass production: A review of breeding activities and genetic gains in Scandinavia and Finland. Uppsala: Skogforsk.

Jansons, A. (2008). Genotype-environment interaction in Latvian Scots pine growth and quality traits and its impact to progeny testing. In: Z. Gaile (ed.) Proceeding of international scientific conference Research for Rural Development, 21-23 of May 2008 (pp. 128-136). Jelgava, Latvija: LLU.

Jansons, Ā., Gailis, A., \& Donis, J. (2011). Profitability of silver birch (Betula pendula Roth.) breeding in Latvia. In: Z. Gaile (ed.) Proceedings of the $17^{\text {th }}$ international scientific conference Research for Rural Development, 18-20 May 2011 (pp. 33.-38). Jelgava, Latvia: LLU.

Jansons, A., Donis, J., Danusevičius, D., \& Baumanis, I. (2015a). Differential analysis for next breeding cycle for Norway spruce in Latvia. Baltic Forestry. 21(2), 285-297.

Jansons, Ā., Matisons, R., Zadina, M., Sisenis, L., \& Jansons, J. (2015b). The effect of climatic factors on height increment of Scots pine in sites differing by continentality in Latvia. Silva Fennica. 49 (3), 14p.

Jansons, Ā., Matisons, R., Krišāns, O., Džeriņa, B., \& Zeps, M. (2016a). Effect of initial fertilization on 34-year increment and wood properties of Norway spruce in Latvia. Silva Fennica. 50 (1), 8 p. DOI: 10.14214/ sf.1346. 
Jansons, Ā., Matisons, R., Šēnhofa, S., Katrevičs, J., \& Jansons, J. (2016b). High-frequency variation of tree-ring width of some native and alien tree species in Latvia during the period 1965-2009. Dendrochronologia. 40, 151-158.

Jansson, G., Danusevičius, D., Grotehusman, H., Kowalczyk, J., Krajmerova, D., Skrøppa, T., \& Wolf, H. (2013). Norway spruce (Picea abies (L.) H. Karst.). Pâques L. (ed.) Forest Tree Breeding in Europe. Managing Forest Ecosystems, (Vol. 25, pp. 123-176). Springer, Dordrecht.

Katrevics, J., Neimane, U., Dzerina, B., Kitenberga, M., Jansons, J., \& Jansons, A. (2018). Environmental factors affecting formation of lammas shoots in young stands of Norway spruce (Picea abies Karst.) in Latvia. iForest, 11, 809-815. DOI: 10.3832/ifor2539-011.

Katrevičs, J., Džeriņa, B., Neimane, U., Desaine, I., Bigača, Z., \& Jansons, Ā. (2018). Production and profitability of low density Norway spruce (Picea abies (L.) Karst.) plantation at 50 years of age: case study from eastern Latvia. Agronomy Research. 16, DOI: 10.15159/AR.18.014.

Kitenberga, M., Jansons, A., Drobyshev, I., Matisons, R., Niklasson, M., Katrevics, J., Adamovics, A., \& Elferts, D. (2019). A mixture of human and climatic effects shapes the 250-year long fire history of a semi-natural pine dominated landscape of Northern Latvia. Forest Ecology and Management. 441, 192-201. DOI: 10.1016/j.foreco.2019.03.020.

Kitenberga, M., Matisons, R., Jansons, A., \& Donis, J. (2018). Teleconnection between the Atlantic sea surface temperature and forest fires in Latvia and Estonia. Silva Fennica. 52 (1), 8 p. DOI: 10.14214/sf.7771.

Lībiete, Z., Matisons, R., Rieksts-Riekstins, J., Priedītis, A., Jansons, J., Smilga, J., Done, G., \& Jansons, A. (2017). Aboveground biomass equations of 40 year old Norway spruce in Latvia. Baltic Forestry. 23(2), $515-521$.

Lībiete-Zālīte, Z., \& Jansons, Ā. (2011). Influence of genetic factors on Norway spruce (Picea abies (L.) Karst.) above-ground biomass and its distribution. In: Z. Gaile (ed.) Proceedings of the $17^{\text {th }}$ international scientific conference Research for Rural Development, 18-20 May 2011 (pp. 39-45). Jelgava, Latvia: LLU.

Matisons, R., Adamovičs, A., Jansone, D., Bigača, Z., \& Jansons, Ā. (2018). Climatic Sensitivity of the TopPerforming Provenances of Scots Pine in Latvia. Baltic Forestry. 24(2), 228-233.

Matisons, R., Puriņa, L., Adamovičs, A., Robalte, L., \& Jansons, Ā. (2017). European beech in its northeasternmost stands in Europe: Varying climate-growth relationships among generations and diameter classes. Dendrohronologia. Vol. 45, 123-131 pp., DOI: 10.1016/j.dendro.2017.08.004.

Pretzsch, H., Biber, P., Schütze, G., Uhl, E., \& Rötzer, T. (2014). Forest stand growth dynamics in Central Europe have accelerated since 1870. Nature Communications. 5. DOI: 10.1038/ncomms5967.

Runǵis, D., Luguza, S., Bāders, E., Šķipars, V., \& Jansons, Ā. (2019). Comparison of Genetic Diversity in Naturally Regenerated Norway Spruce Stands and Seed Orchard Progeny Trials. Forests, 10, 926; DOI: 10.3390/f10100926.

Rieksts-Riekstins, J., Jansons, A., Smilga, J., Baumanis, I., Ray, D., \& Connolly, T. (2014). Climate suitability effect on tree growth and survival for Scots pine provenances in Latvia. In: Z. Gaile (ed.) Proceedings of the $20^{\text {th }}$ international scientific conference Research for Rural Development, 21-23 May 2014 (pp. 57-62). Jelgava, Latvia: LLU.

Seidl, R., Schelhaas, M.-J., Rammer, W., \& Verkerk, P.J. (2014). Increasing forest disturbances in Europe and their impact on carbon storage. Nature Climate Change, 4, 806-810. DOI: 10.1038/nclimate2318.

Schmidt-Vogt, H. (1977). Die Fichte. Ein Handbuch in zwei Bänden. I Taxonomie, Verbreitung, Morphologie, Ökologie, Waldgesellschaften. XVIII + 647 S., 304 Abb., 60 Übersichten. Verlag Paul Parey, Hamburg, Berlin. ISBN 3490082168.

Zeltiņš, P., Katrevičs, J., Gailis, A., Maaten, T., Bāders, E., \& Jansons, Ā. (2018a). Effect of Stem Diameter, Genetics, and Wood Properties on Stem Cracking in Norway Spruce. Forests, 9, 546; DOI: 10.3390/ f9090546.

Zeltiņš P., Matisons R., Gailis A., Jansons J., Katrevičs J., \& Jansons, Ā. (2018b). Genetic parameters of growth traits and stem quality of silver birch in a low-density clonal plantation. Forests, 9(2), 52. DOI: 10.3390/ f9020052.

Zeltiňš, P., Katrevičs, J., Gailis, A., Maaten, T., Jansons, J., \& Jansons, Ā. (2016). Stem cracks of Norway spruce (Picea abies (L.) Karst.) provenances in Western Latvia. Forestry Studies. 65, 57-63. 